\title{
The Effect of Frequency of Dialysis Session On Efficiency of Brain Natriuretic Peptide as Cardiac Biomarker Among Patient with End Stage Renal Disease
}

\author{
Dr. Abdul-Aziz A. Azizi, ${ }^{1, *}$ Dr. Abdul-Hassan M. Salih ${ }^{2}$ \\ ${ }^{1}$ University of Telafer, Ninewa, Iraq. \\ ${ }^{2}$ University of Thiqar, Thiqar, Iraq. \\ *Corresponding author. Email: abahaz1957@yahoo.com
}

\begin{abstract}
Background: There is overwhelming evidence about the importance of brain natriuretic peptide as a cardiac biomarker. However, the hemodynamic changes and associated abnormal body fluid homeostasis in patient with impaired renal function will add further complexity to the situation and may make the validity of brain natriuretic peptide as predictor of heart performance questionable. This prospective cross-sectional study tends to appraise the role of brain natriuretic peptide in determining left ventricular performance in patient with end stage renal disease treated by regular haemodialysis and its relation to the frequency of dialysis.

Methods: the present study included ninety patients with end stage renal disease who attend Al-Hussein hospital in Thiqar governorate /Iraq for regular haemodialysis. The patients were further classified into 3 groups depending on the frequency of dialysis session. Ten $\mathrm{ml}$ of venous blood were taken from every patient to measure the plasma level of brain natriuretic peptide and creatinine. Glomerular filtration rate was estimated from plasma creatinine values utilizing Cockcroft-Gault equation. Left ventricular ejection fraction was determined by transthoracic two-dimensional echocardiography. Chi-square test used to assess the relationship between different studied variables. The relation considered significant when $\mathrm{P}$ value $<0.05$.

Results: There was a statistically significant negative relation between the plasma level of brain natriuretic peptide and left ventricular ejection fraction $(\mathrm{P}<0.001)$. The mean of plasma level of brain natriuretic peptide was significantly higher $(\mathrm{P}<0.001)$ in patients who underwent single dialysis each week when compared with patients who underwent three dialysis session each week. There was a strong negative association $(\mathrm{P}<0.001)$ between the renal function represented by the mean of glomerular filtration rate and level of brain natriuretic peptide in the plasma.

Conclusion: Estimation of brain natriuretic peptide values in the plasma seems to be efficient in predicting left ventricular function among patients with end stage renal disease. However, utilizing brain natriuretic peptide measurement together with estimation of left ventricular ejection fraction seems to be necessary in these patients to avoid the bias in brain natriuretic peptide level which may contribute to other factors like volume status or impaired excretion of BNP rather than impaired left ventricular function.
\end{abstract}

Keywords: Left Ventricular Function, End Stage Renal Disease, Brain Natriuretic Peptide, Dialysis Frequency.

\section{INTRODUCTION}

Brain natriuretic peptide (BNP) is a counter regulatory peptide related to the family of natriuretic peptide which include also urodilatin, atrial natriuretic peptide (ANP), C-type natriuretic peptide (CNP) and dendroaspis-type natriuretic peptide (DNP) ${ }^{(1)}$. The main function of BNP includes vasodilation, diuresis, natriuresis, antagonizing the effects of the reninangiotensin aldosterone system and damping the activity of sympathetic system ${ }^{(2,3,4)}$. Brain natriuretic peptide secretion is stimulated by any condition that increase ventricular wall myocyte stretch ${ }^{(5,6)}$. End Stage Renal Disease (ESRD) is one of the main health 
care problems that challenge health authorities worldwide, it kills millions of populations each year ${ }^{(7)}$. Glomerular filtration rate (GFR) is an essential tool of assessing renal function and aid in diagnosis and classification of ESRD ${ }^{(8)}$. Cardiovascular disease is very common among patients with ESRD and represent the principal cause of complications and death among these patients ${ }^{(9,10)}$. Precocious determination of left ventricular (LV) function in patients with ESRD seems to be essential strategy of management of these patients. The primary stimulus for secretion of BNP among patients with ESRD is ventricular hypertrophy which is a common finding among these patients ${ }^{(11)}$. However, patients with impaired renal function fail to excrete adequate amount of water and electrolyte, which predispose to more increase in body fluid volume with further increase in BNP secretion by ventricular myocytes ${ }^{(12,13)}$. The aim of this prospective crosssectional study is to assess the effect of dialysis session frequency on the efficiency of BNP in predicting the performance of $\mathrm{LV}$ in patient with ESRD treated by regular haemodialysis (HD).

\section{SUBJECTS, MATERIALS AND METHODS}

This prospective cross-Sectional study conducted on ninety patients with ESRD treated with HD. These patients were selected randomly from over all patients with ESRD who attend Al-Hussien hospital in Thiqar governorate/Iraq for HD, from March 2017 to April 2018. All patients included in this study had normal LV function as manifested by normal values of cardiac ejection fraction $(\mathrm{EF} \%)$. Forty-six of them are males and remaining 44 are females with their ages range from 25-65years. Depending on the frequency of dialysis process performed weekly, they were classified into 3 groups, group I (4 patients) underwent one dialysis session every week, group II (34 patients) underwent two dialysis session every week, and group III (52 patients) underwent three dialysis session each week. Dialysis process performed with patients on supine state, the average time of each dialysis session is 3 hours. Concerning the ethical issues, the principle and steps of the study were explained to participant and a written consent was obtained from every patient.

Ten $\mathrm{ml}$ of venous blood was obtained from every patient from a suitable vein, for the estimation of plasma level of creatinine and BNP. Depending on plasma creatinine values, creatinine clearance (Ccr) was calculated for every patient by utilizing CockcroftGault equation ${ }^{(14)}$, the values of estimated creatinine clearance was taken as index of glomerular filtration rate (GFR) after correction for age, gender and body surface area:
(140- age /years) $\mathrm{x}$ body weight $/ \mathrm{kg}$

$$
\mathrm{C}_{\mathrm{Cr}}=\frac{}{\mathrm{mL} / \mathrm{min}} \quad \mathrm{PCr}(\mathrm{mg} / \mathrm{dL}) \times 72
$$

The LV function was determined by calculating EF\% utilizing M-mode echocardiogram ${ }^{(15)}$.

Statistical package of social science version 23 (SPSS) was used to study the association between different studied parameters using Chi-square test, the test considered significant statistically when $\mathrm{P}$ value < 0.05 .

\section{RESULTS}

The effect of frequency of dialysis session on plasma level of brain natriuretic peptide

Table (1), Shows the values of the plasma level of BNP in patients with ESRD who underwent different number of dialysis session each week. There was a statistically significant negative association $(\mathrm{P}<0.0001)$ between number of dialysis sessions per week and plasma level of BNP. The plasma level of BNP tends to be higher among patients who had only one session of dialysis per week and exhibit lower values among patients who underwent two or three session of dialysis per week as shown in table (1).

Table (1): The values of the plasma level of brain natriuretic peptide in patients with End Stage Renal Disease who underwent different number of dialysis session each week.

\begin{tabular}{|c|c|c|c|c|c|}
\hline \multirow{2}{*}{$\begin{array}{r}\text { No. of } \\
\text { dialysis } \\
\text { / week }\end{array}$} & \multicolumn{4}{|c|}{ Brain natriuretic peptide $\mathrm{pg} / \mathrm{ml}$} & \multirow{2}{*}{$\begin{array}{l}\mathrm{X} 2 \\
\mathrm{P} \text { value }\end{array}$} \\
\hline & $<125$ & $\begin{array}{c}125 \\
- \\
450\end{array}$ & $>450$ & $\begin{array}{c}\text { TOTA } \\
\text { L }\end{array}$ & \\
\hline $\begin{array}{l}\text { Three } \\
\text { session }\end{array}$ & $\begin{array}{c}6 \\
(11.5 \%\end{array}$ & $\begin{array}{l}41 \\
(79\end{array}$ & $\begin{array}{c}5 \\
(9.5 \%\end{array}$ & $\begin{array}{c}52 \\
(100 \%)\end{array}$ & \multirow{4}{*}{$\begin{array}{c}16.00 \\
3 \\
0.000 \\
1\end{array}$} \\
\hline $\mathrm{s}$ & ) & $\%)$ & ) & & \\
\hline $\begin{array}{c}\text { Two } \\
\text { session } \\
\mathrm{s}\end{array}$ & $\begin{array}{c}14 \\
(41 \%)\end{array}$ & $\begin{array}{l}14 \\
(41 \\
\%)\end{array}$ & $\begin{array}{c}6 \\
(18 \%)\end{array}$ & $\begin{array}{c}34 \\
(100 \%)\end{array}$ & \\
\hline $\begin{array}{c}\text { One } \\
\text { Session }\end{array}$ & $\begin{array}{c}0 \\
(0 . \\
0 \%)\end{array}$ & $\begin{array}{c}1 \\
(25 \\
\%)\end{array}$ & $\begin{array}{c}3 \\
(75 \%)\end{array}$ & $\begin{array}{c}4 \\
(100 \%)\end{array}$ & \\
\hline $\begin{array}{c}\text { TOTA } \\
\text { L }\end{array}$ & 20 & 56 & 14 & 90 & \\
\hline
\end{tabular}

Renal function and plasma level of brain natriuretic peptide among patients with End Stage Renal Disease.

There was a statistically significant negative association between ventricular performance manifested by plasma level of BNP and renal function exhibited by GFR. The values of BNP were significantly higher in patient with GFR values less than $15 \mathrm{ml} / \mathrm{min}$. in comparison with those patients who 
had GFR values greater than $15 \mathrm{ml} / \mathrm{min}$. ( $\mathrm{P}$ value $=0.001)$, as shown in table (2).

Table (2): plasma level of brain natriuretic peptide and glomerular filtration rate among patients with End Stage Renal Disease.

\begin{tabular}{|c|c|c|c|c|c|}
\hline \multirow{2}{*}{$\begin{array}{l}\text { GFR } \\
\mathrm{ml} / \mathrm{min}\end{array}$} & \multicolumn{3}{|c|}{ Brain natriuretic peptide $\mathrm{pg} / \mathrm{ml}$} & \multirow[t]{2}{*}{ Total } & \multirow{2}{*}{$\begin{array}{l}\mathrm{X} 2 \\
\mathrm{p} \\
\text { value }\end{array}$} \\
\hline & $<125$ & $126-450$ & $>450$ & & \\
\hline$<15$ & $\begin{array}{c}8 \\
(40 \%)\end{array}$ & $\begin{array}{c}25 \\
(46.4 \%)\end{array}$ & $\begin{array}{c}13 \\
(92.3 \\
\%)\end{array}$ & 46 & \multirow[t]{2}{*}{$\begin{array}{c}26.4 \\
14 \\
.001\end{array}$} \\
\hline$>15$ & $\begin{array}{c}12 \\
(60 \%)\end{array}$ & $\begin{array}{c}31 \\
(53.6 \%)\end{array}$ & $\begin{array}{c}1 \\
(7.7 \%)\end{array}$ & 44 & \\
\hline total & $\begin{array}{c}20 \\
(100 \%)\end{array}$ & $\begin{array}{c}56 \\
(100 \%)\end{array}$ & $\begin{array}{c}14 \\
(100 \%)\end{array}$ & 90 & \\
\hline & & & & & \\
\hline
\end{tabular}

Left ventricular performance and plasma level of brain natriuretic peptide

There was a statistically significant negative association $(\mathrm{P}<0.0001)$ between the mean of EF \% of $\mathrm{LV}$ and plasma level of BNP in patients with ESRD included in this study. The majority of patients with EF\% values ranging from 56 to $70 \%$ had plasma level of BNP less than $450 \mathrm{pg} / \mathrm{ml}$, while most patients who had $\mathrm{EF} \%$ values ranging from 40 to $55 \%$ had plasma level of BNP more than $450 \mathrm{pg} / \mathrm{ml}$, as shown in table (3).

Table (3): plasma level of BNP and left ventricular EF\% in patients with End Stage Renal Disease.

\begin{tabular}{|l|c|c|c|c|c|}
\hline \multirow{2}{*}{$\begin{array}{l}\text { EF } \\
\%\end{array}$} & \multicolumn{3}{|c|}{ Brain natriuretic peptide pg/ml } & Total & $\begin{array}{c}\text { X2 } \\
\mathrm{p} \\
\text { value }\end{array}$ \\
\cline { 2 - 4 } $\begin{array}{c}56- \\
70\end{array}$ & $\begin{array}{c}20 \\
(31.2 \\
\%)\end{array}$ & $\begin{array}{c}425-450 \\
(68.8 \%)\end{array}$ & $\begin{array}{c}>450 \\
(0.0 \% \\
)\end{array}$ & $\begin{array}{c}64 \\
(100 \\
\%)\end{array}$ & 29.4 \\
\hline $\begin{array}{c}40- \\
55\end{array}$ & $\begin{array}{c}0 \\
(0.0\end{array}$ & $\begin{array}{c}12 \\
(46.2 \%)\end{array}$ & $\begin{array}{c}14 \\
(53.8 \\
\%)\end{array}$ & $\begin{array}{c}26 \\
(100 \\
\%)\end{array}$ & $\begin{array}{c}.000 \\
1\end{array}$ \\
\hline $\begin{array}{l}\text { Tot } \\
\text { al }\end{array}$ & 20 & 56 & 14 & 90 & \\
\hline
\end{tabular}

Renal function and frequency of dialysis sessions per week among patients with End Stage Renal Disease.

There was a statistically significant positive relationship between frequency of dialysis sessions per week and the renal function test represented by GFR values. The patients who had only one dialysis session per week found to had low GFR values. On the other hand, patients who had two or three dialysis session weekly had higher GFR $(\mathrm{p}<0.001)$ as shown in table (4).
Table (4): The values of glomerular filtration rate among patients with End Stage Renal Disease in relation to frequency of dialysis.

\begin{tabular}{|c|c|c|c|c|}
\hline \multirow{2}{*}{$\begin{array}{l}\text { No. of } \\
\text { dialysis/ } \\
\text { week }\end{array}$} & \multicolumn{3}{|c|}{ Glomerular filtration rate $\mathrm{ml} / \mathrm{min}$} & \multirow{2}{*}{$\begin{array}{l}\mathrm{X} 2 \\
\mathrm{P} \text { value }\end{array}$} \\
\hline & $\begin{array}{c}>15 \\
\mathrm{ml} / \mathrm{min}\end{array}$ & $\begin{array}{c}<15 \\
\mathrm{ml} / \mathrm{min}\end{array}$ & TOTAL & \\
\hline $\begin{array}{c}\text { Three } \\
\text { sessions }\end{array}$ & $\begin{array}{c}32 \\
(61.5 \%)\end{array}$ & $\begin{array}{c}20 \\
(38.5 \%)\end{array}$ & $\begin{array}{c}52 \\
(100 \%)\end{array}$ & \multirow{3}{*}{$\begin{array}{l}14.264 \\
0.0001\end{array}$} \\
\hline $\begin{array}{c}\text { Two } \\
\text { sessions }\end{array}$ & $\begin{array}{c}11 \\
(32.3 \%)\end{array}$ & $\begin{array}{c}23 \\
(67.7 \%)\end{array}$ & $\begin{array}{c}34 \\
(100 \%)\end{array}$ & \\
\hline $\begin{array}{c}\text { One } \\
\text { Session }\end{array}$ & $\begin{array}{c}1 \\
(25 \%)\end{array}$ & $\begin{array}{c}3 \\
(75 \%)\end{array}$ & $\begin{array}{c}4 \\
(100 \%)\end{array}$ & \\
\hline Total & 44 & 46 & 90 & \\
\hline
\end{tabular}

The relationship between left ventricular EF\% and frequency of dialysis sessions among patients with End Stage Renal Disease.

The result of study showed a statistically significant positive relationship $(\mathrm{p}<0.005)$ between values of left ventricular $\mathrm{EF} \%$ and number of dialysis sessions per week among patients with ESRD. The patients who had only one session of dialysis each week exhibit low cardiac performance manifested by low value of left ventricular EF\%. However, patient who underwent two or three session of dialysis per week found to have better cardiac performance manifested by high values of left ventricular EF\%, as shown in table (5).

Table (5): The values of left ventricular EF\% in relation to the number of dialysis sessions every week among patients with End Stage Renal Disease.

\begin{tabular}{|c|c|c|c|c|}
\hline \multirow{2}{*}{$\begin{array}{c}\text { No. of } \\
\text { dialysis/ } \\
\text { week }\end{array}$} & \multicolumn{3}{|c|}{ Ejection fraction $\%$} & \multirow{2}{*}{$\begin{array}{c}\mathrm{X} 2 \\
\mathrm{P} \text { value }\end{array}$} \\
\hline & $40-55$ & $56-70$ & TOTAL & \\
\hline $\begin{array}{c}\text { One } \\
\text { Session }\end{array}$ & $\begin{array}{c}3 \\
(75 \%)\end{array}$ & $\begin{array}{c}1 \\
(25 \%)\end{array}$ & $\begin{array}{c}4 \\
(100 \%)\end{array}$ & \multirow{3}{*}{$\begin{array}{c}10.004 \\
0.005\end{array}$} \\
\hline $\begin{array}{c}\text { Two } \\
\text { sessions }\end{array}$ & $\begin{array}{c}11 \\
(32.3 \%)\end{array}$ & $\begin{array}{c}23 \\
(67.7 \%)\end{array}$ & $\begin{array}{c}34 \\
(100 \%)\end{array}$ & \\
\hline $\begin{array}{c}\text { Three } \\
\text { sessions }\end{array}$ & $\begin{array}{c}12 \\
(23 \%)\end{array}$ & $\begin{array}{c}40 \\
(77 \%) \\
\end{array}$ & $\begin{array}{c}52 \\
(100 \%) \\
\end{array}$ & \\
\hline Total & 26 & 64 & 90 & \\
\hline
\end{tabular}

\section{DISCUSSION}

The subject of natriuretic peptides attracts great attention in the last decades and a large number of researches in this aspect showed the importance of these peptides and specially BNP in determining LV performance among general population with normal renal function (16,17). However, patients with ESRD represent special pathophysiological entity where a lot of factors tend to exert extra burden on cardiovascular system and may alter the efficiency of BNP as excellent cardiac biomarker among these patients. The finding of this study showed that BNP is efficient marker of LV 
performance among patients with ESRD as manifested by a statistically significant negative association $(\mathrm{P}<$ 0.0001) between plasma levels of BNP and left ventricular EF \%.

The data of this paper consolidate the observation reported by many previous researches and confirm the role of BNP as excellent biomarker of left ventricular function in patients with ESRD (18,19,20,21). Left ventricular hypertrophy is common finding among patients with ESRD, this abnormality is possibly the main stimulus for increase plasma level of BNP among these patients ${ }^{(20,21,21)}$. Sommerer $C$, etal. found that BNP levels were almost invariably elevated in patients with ESRD who maintained on HD or peritoneal dialysis compared with the normal cutoff values ${ }^{(25)}$. Cardiovascular involvement among patients with ESRD is a complex puzzle, several mechanisms my contribute to such abnormality like hemodynamic alteration ${ }^{(26,27)}$, the inflammatory process associated with chronic kidney disease ${ }^{(28,29,30)}$, dyslipidemia ${ }^{(31 ., 32)}$, and associated pathological changes in the structure of cardiac myocytes known as uremic cardiomyopathy $(33,34,35)$.

In fact, the interpretation of elevated plasma level of BNP among patients with ESRD seems to be multifactorial. Expansion of body fluid volume may be an additional cause to elevated plasma level of BNP among these patients ${ }^{36,37,38)}$

It is well-known that kidneys are the major site of excretion of different substances including $\mathrm{BNP}^{(39)}$, in fact patients with ESRD exhibit a tremendous decline in renal excretory function ${ }^{(40,41)}$. This fact explains in part the extra increase in plasma BNP level among patients with ESRD included in this study, it also identifies why patients who underwent frequent dialysis tend to manifest lower plasma level of BNP than those patients who had only one HD each week. This finding again indicate that impaired renal excretion of the peptide may contribute to high BNP among patients with ESRD in addition to cardiovascular disorders and volume expansion.

One of the exciting findings in this study is that patients with ESRD who receive frequent dialysis tend to exhibit a better renal performance in comparison with those who had less frequent dialysis as explained by statistically significant higher values of GFR among patients receiving more dialysis session.

\section{DISCUSSION}

In conclusion estimation of plasma level of BNP seems to be efficient in predicting $\mathrm{LV}$ function in hemodialyzed patients. However, utilizing BNP measurement together with assessment of left ventricular EF\% among patients with ESRD appear to be necessary to avoid the bias in BNP level which may contribute to other factors like volume status or impaired excretion of BNP rather than impaired LV function.

\section{CONCLUSION}

Estimation of brain natriuretic peptide values in the plasma seems to be efficient in predicting left ventricular function among patients with end stage renal disease. However, utilizing brain natriuretic peptide measurement together with estimation of left ventricular ejection fraction seems to be necessary in these patients to avoid the bias in brain natriuretic peptide level which may contribute to other factors like volume status or impaired excretion of BNP rather than impaired left ventricular function.

\section{REFERENCES}

[1] Martinez-Rumayor A, Richards AM, Burnett JC, et al. Biology of the natriuretic peptides. Am J Cardiol, 2008;101: 3-8.

[2] Marc Vanderheyden, Jozef Bartunek, Marc Goethals. Brain and other natriuretic peptides: molecular aspects. Eu J heart failure, 2004;6: 261 268.

[3] Philip Ching Yat Wong, Jun Guo, Aidong Zhang. The renal and cardiovascular effects of natriuretic peptides. AJP Advances in Physiology Education, 2017; 41(2):179-185.

[4] Wong PC, Guo J, Zhang A. The renal and cardiovascular effects of natriuretic peptides. Adv Physiol Educ. 2017;41(2):179-185.

[5] Woodard GE, Rosado JA. Natriuretic peptides in vascular physiology and pathology. Int Rev Cell Mol Biol. 2008;268:59-93.

[6] Daniels LB., Maisel AS. Natriuretic peptides. J Am Coll Cardiol ,2007; 50: 2357-2368.

[7] Lozano R, Naghavi M, Foreman K, et al. Global and regional mortality from 235 causes of death for 20 age groups in 1990 and 2010: A systematic analysis for the Global Burden of Disease Study 2010. Lancet 2012:380:2095-2128.

[8] National Kidney foundation. K/DOQI clinical practice guidelines for chronic kidney disease: evaluation, classification, and stratification. Am J Kidney Dis 2002; 39: s1-266.

[9] Stephanie Thompson, Matthew James, Natasha Wiebe, et al. Cause of death in patients with reduced kidney function. JASN 2015;26 (10): 2504-2511.

[10] Sanyaolu A, Okorie C, Annan R, et al. Epidemiology and management of chronic renal 
failure: a global public health problem. Biostatistics Epidemiol Int J. 2018 ;1(1): 11-16.

[11] David G. Gardner, Songcang Chen, Denis J. Glenn, etal. Molecular Biology of the Natriuretic Peptide System. Implications for Physiology and Hypertension. Hypertension. 2007; 49:419-426.

[12] Jae Won Yang, Min Soo Kim, Jae Seok Kim, etal. Relationship between serum brain natriuretic peptide and heart function in patients with chronic kidney disease. Korean J Intern Med. 2008; 23(4): 191-200.

[13] Volpe, M. Natriuretic peptides and cardio-renal disease. Int. J. Cardiol. 2014; 176: 630-639.

[14] Cockcroft DW, Gault MH: Prediction of creatinine clearance from serum creatinine. Nephron. 1976; 16: 31-41.

[15] Lang RM, Badano LP, Mor-Avi V, etal. Recommendations for cardiac chamber quantification by echocardiography in adults: an update from the American Society of Echocardiography and the European Association of Cardiovascular Imaging. J Am Soc Echocardiogr. 2015 ;28(1):1-39.

[16].Abdul-Aziz Ahmed Aziz, Fadhila Shahwan AlDoski, Shaker M. Suliman. The relation of plasma level of atrial and brain natriuretic peptides to left ventricular function in hypertensive patients. Annals of the College of Medicine Mosul, 2005;31:52-56.

[17] Abdul - Aziz Ahmed Aziz, Yesar M.H. AlShamma., Dr. Riyad Waheed. The relation of plasma level of atrial and brain natriuretic peptide to left ventricular function in subjects with congenital heart disease. Kufa Med.Journal 2011; 14:1-9.

[18] Mallamaci F, Zoccali C, Tripepi G, et al. Diagnostic potential of cardiac natriuretic peptides in dialysis patients. Kidney Int 2001; 59:1559_ 1566.

[19] Abdul-Aziz, Ahmed Aziz. Plasma level of atrial natriuretic peptide in chronic renal failure on maintenance hemodialysis: effect of heart failure. (Ann Coll Med Mosul 2005; 31:32 -36.

[20] Volpe, M. Natriuretic peptides and cardio-renal disease. Int. J. Cardiol. 2014, 176, 630-639.

[21] Savoj J. Becerra B. Kim J.K. Utility of Cardiac Biomarkers in the Setting of Kidney Disease. Nephron 2019; 141:227-235.

[22] DeFilippi C, van Kimmenade RR, Pinto YM. Amino terminal pro-B-type natriuretic peptide testing in renal disease. Am J Cardiol 2008; 101:82-88.

[23] Wang AY, Lai KN. Use of cardiac biomarkers in end-stage renal disease. J Am Soc Nephrol 2008; 19:1643-1652.

[24] Victor Hajjar, Martin J. Schreiber, Jr., Does measuring natriuretic peptides have a role in patients with chronic kidney disease? Cleveland Clinic Journal of Medicine. 2009;76(8):476-478.

[25] Sommerer C, Giannitsis E, Schwenger V, Zeier M: Cardiac biomarkers in haemodialysis patients: The prognostic value of amino terminal pro-B-type natriuretic peptide and cardiac troponin $\mathrm{T}$. Nephron Clin Pract,2007; 107: c77-c81.

[26] Brunet P, Gondouin B, Duval-Sabatier A, etal. Does uremia cause vascular dysfunction? Kidney Blood Press Res, 2011; 34:284-290.

[27] Fujii H, Goto S, Fukagawa M. Role of uremic toxins for kidney, cardiovascular, and bone dysfunction. Toxins, 2018; 10:202-220.

[28] Kielstein JT, Veldink H, Martens-Lobenhoffer J, etal. Unilateral nephrectomy causes an abrupt increase in inflammatory mediators and a simultaneous decrease in plasma ADMA: a study in living kidney donors. Am J Physiol Renal Physiol. 2011; 301: F1042-F1046.

[29] Zoccali C, Vanholder R, Massy ZA, et al.; European Renal and Cardiovascular Medicine (EURECA-m) Working Group of the European Renal Association - European Dialysis Transplantation Association (ERA-EDTA). The systemic nature of CKD. Nat Rev Nephrol. 2017; 13:344-358.

[30] Amdur RL, Feldman HI, Dominic EA, Anderson AH, Beddhu S, Rahman M, Wolf M, Reilly M, Ojo A, Townsend RR, et al.; CRIC Study Investigators. Use of measures of inflammation and kidney function for prediction of atherosclerotic vascular disease events and death in patients with CKD: findings from the CRIC Study. Am J Kidney Dis. 2019; 73:344-353.

[31] Shroff R, Speer T, Colin S, et al. HDL in children with CKD promotes endothelial dysfunction and an abnormal vascular phenotype.J Am Soc Nephrol. 2014; 25:2658-2668.

[32] Zewinger S, Kleber ME, Rohrer L, et al. Symmetric dimethylarginine, high-density lipoproteins and cardiovascular disease.Eur Heart J. 2017; 38:1597-1607. 
[33] Glassock RJ, Pecoits-Filho R, Barberato SH. Left ventricular mass in chronic kidney disease and ESRD. Clin J Am Soc Nephrol. 2009;(4 suppl 1): S79-S91.

[34] Alhaj E, Alhaj N, Rahman I, etal. Uremic cardiomyopathy: an underdiagnosed disease. Congest Heart Fail. 2013; 19: E40-E45.

[35] Di Lullo L, Gorini A, Russo D, etal. Left ventricular hypertrophy in chronic kidney disease patients: from pathophysiology to treatment. Cardiorenal Med. 2015; 5:254-260.

[36] Spanaus KS, Kronenberg F, Ritz E, et al. B-type natriuretic peptide concentrations predict the progression of nondiabetic chronic kidney disease: the mild-to-moderate kidney disease study. Clin Chem. 2007; 53:1264-1272.

[37] TakayoshiTsutamoto, Atsuyuki Wada, Hiroshi Sakai,etal. Relationship Between Renal Function and Plasma Brain Natriuretic Peptide in Patients with Heart Failure. JACC ,2006; 47(3): 582-586.

[38] Joachim Jankowski, Jürgen Floege, Danilo Fliser, etal. Cardiovascular Disease in Chronic Kidney Disease. Pathophysiological Insights and Therapeutic Options. Circulation. 2021; 143:1157-1172.

[39] Roland R. J., van Kimmenade, James L, Januzzi, JR, etal. Renal Clearance of B-Type Natriuretic Peptide and Amino Terminal Pro-B-Type Natriuretic Peptide. J Am Coll Cardiol 2009; 53:884-890.

[40] Levey AS, Eckardt KU, Tsukamoto Y, et al. Definition and classification of chronic kidney disease: a position statement from kidney disease: improving global outcomes (KDIGO). Kidney Int 2005; 67:2089-2100.

[41] Robert Thomas, Abbas Kanso, John R. Sedor. Chronic Kidney Disease and Its Complications. Prim Care Clin Office Pract ,2008;35: 329-344. 